\title{
CONVECTION HEAT TRANSFER MODELING OF AG NANOFLUID USING DIFFERENT VISCOSITY THEORIES
}

\author{
M.Ayatollahi, Sh.NASIRI AND A.B. KASAEIAN \\ Faculty of New Science \& Technology, University of Tehran, Iran. \\ Tehran, Iran. \\ alikasa20@gmail.com
}

\begin{abstract}
In this paper, the effects of adding nanoparticles (including Ag) to a fluid media for improving free convection heat transfer were analysed. The free convective heat transfer was assumed to be in laminar flow regime, and the corresponding calculations and solutions were all done by the integral method. Water, as a Newtonian fluid, was considered as the base and all relevant thermo physical properties of the nanofluids were considered to be unvarying. The calculations performed and the graphs generated showed that, in general, the addition of nanoparticles to the fluid media resulted in an increment or improvement of its heat transfer coefficient. With increase in the concentration of the nanoparticles, the heat transfer rate of the fluid also increased. The increment in heat transfer is also dependent on the nanoparticles' thermal conductivity and the viscosity theory which was utilized in the calculations. In this study, four different theories were used to calculate the viscosities of the nanofluids. The effects of viscosity on the nanofluids' thermal conductivity were apparent from the calculations which were performed for nanoparticle concentrations of $4 \%$ or less.
\end{abstract}

ABSTRAK: Kajian ini menganalisis kesan penambahan nanopartikel Ag ke dalam media bendalir bagi tujuan pembaikkan pemindahan haba perolakan bebas. Perolakan bebas diandaikan berada di zon aliran laminar, di mana penyelesaian dan pengiraan telah dilakukan mengunakan kaedah kamilan. Air yang merupakan cecair Newtonian, dianggap sebagai asas dan sifat terma fizikal nanocecair dianggapkan tidak berubah. Mengikut pengiraan yang dilakukan dan graf yang diplotkan, umumnya penambahan nanopartikel kepada media bendalir menyebabkan peningkatan dan pengembangan pekali pemindahan haba. Kadar pemindahan haba meningkat dengan nanopartikel. Peningkatan pemindahan haba juga bergantung kepada pengalir haba nanopartikel dan teori kelikatan yang digunakan. Di dalam kajian ini, empat jenis teori telah digunakan bagi pengiraan kelikatan nanopartikel. Kesan kelikatan ke atas pengalir haba nanocecair sangat jelas kelihatan. Kesemua pengiraan telah dilakukan ke atas kepekatan kurang dari $4 \%$.

KEYWORDS: Ag nanofluid, heat transfer, natural convection

\section{INTRODUCTION}

Optimization of heat transfer in the direction of achieving more efficiency needs concentration on the facilities scale-down and also increasing the heat transfer rate. The conductivity of some metallic particles, metallic oxides and nanotubes is much higher than the conductivity of liquids. According to the novel ideas, adding very tiny particles onto liquids (which makes nanofluids)may develop the heat transfer rate remarkably $[1,2]$. It is obvious that using nanofluids and researches about that subject have been popularized during the recent years. The investigations about forced convection have been mostly 
experimental and practical and the studies about the free convection heat transfer as experimental and theoretical have well grown simultaneously, for $\mathrm{Al}_{2} \mathrm{O}_{3}$ with a volume fraction of 3\% exhibits better enhancement than those for $4 \%$ or $5 \%$, which is still lower than pure water [3]. The studies and experiments show that the forced convection heat transfer of nanofluids is dependent on Reynolds number [4] although beside all the experimental activities about this subject, lack of sufficient information is absolutely evident [5].

Different experiments and studies have been done on the improvement of free convection heat transfer and the results have been published by several papers $[6,7]$. The nanoparticles concentrations highly effect on the convection heat transfer improvement, which is associated with increasing of heat transfer coefficient and the nanoparticles Nusselt number theinfluence of shape of the nanopartice on heat transfer augmentation is simulatedusing an empirical shape of nano parameter which depicts the ratio of surface area to volume of the nanoparticles [8]. Also, some other experimental researches have been done on $\mathrm{Ag} /$ water which have appropriate agreement with the theoretical fundamentals $[9,10]$.

Regarding the obtained results by the performed experimental works, it is crystal clear that the heat transfer coefficient (h) is directly dependent on $\mathrm{k} / \delta_{\mathrm{t}}$ where $\mathrm{k}$ is conductivity and $\delta_{\mathrm{t}}$ is the thickness of thermal boundary layer. One of the main reasons for increasing the heat transfer rate of nanofluids comparing to the base fluid individually, is raising the heat transfer coefficient by adding nanoparticles. Existence of numerous papers about nanofluids, verify the declaration $[11,12]$. The amount of enhancement is dependent on the particle shape, particle type, particle size, particle concentration and kind of base fluid [13]. In the recent works, one can apparently understand that in addition to all the mentioned factors, viscosity is effective on heat transfer improvement and plays a significant role beside the nanoparticles conductivity [14]. For purpose of investigation of viscosity effect on heat transfer coefficient, four different models have been used in this paper. The modeling results have been compared with the similar experimental results. In principle, increasing of random movement of nanoparticles causes thermal conductivity enhancement in nanofluids [15]. In this study, an appropriate mechanical model has been chosen which is solved by integral solution methods. The results may be used for both states of UHF and UWT which can be applied for both laminar and turbulent regimes [16].

\section{MECHANICAL MODEL}

The applied model is a vertical plane which on free convection in laminar conditions occurs. According to Fig. 1, two kinds of boundary conditions including uniform heat flux (UHF) and uniform wall temperature (UWT) may be used for this model.

In reference to what was stated in the introduction, all fluid properties are assumed constant except viscosity. Writing the continuity, momentum and energy equations in directions of $\mathrm{x}$ and $\mathrm{y}$ for steady-state conditions will help us to obtain the target equations. Also the simultaneous solution of the following integrals, considering a four-power polynomial profile for velocity and temperature, leads to the following equations.

$$
\begin{aligned}
& \text { Continuity equation : } \partial \mathrm{U} /(\partial \mathrm{x})+\partial \mathrm{V} / \partial \mathrm{y}=0 \\
& \text { Momentum equation: } \frac{\partial \mathrm{U}}{\partial \mathrm{t}}+\mathrm{U} \frac{\partial \mathrm{U}}{\partial \mathrm{x}}+\mathrm{V} \frac{\partial \mathrm{V}}{\partial \mathrm{y}}=\mathrm{g} \beta\left(\mathrm{T}_{\mathrm{W}}-\mathrm{T}_{\infty}\right)+\mathrm{V} \\
& \text { Energy equation: } \frac{\partial \mathrm{T}}{\partial \mathrm{t}}+\mathrm{U} \frac{\partial \mathrm{T}}{\partial \mathrm{x}}+\mathrm{V} \frac{\partial \mathrm{T}}{\partial \mathrm{y}}=\frac{\vartheta}{\operatorname{Pr}} \frac{\partial^{2} \mathrm{~T}}{\partial \mathrm{y}^{2}}
\end{aligned}
$$




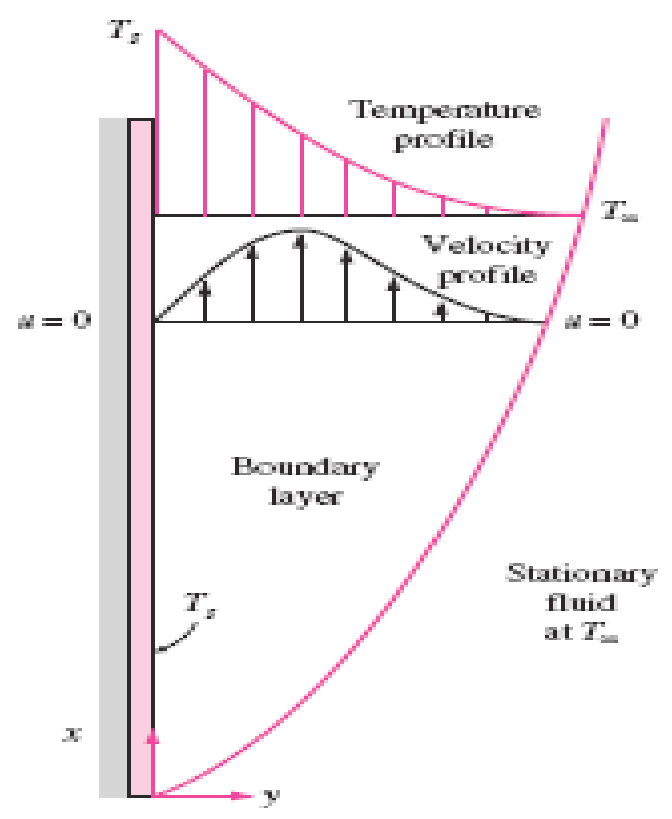

Fig. 1: Temperature and velocity distribution of free convection boundary layer.

Using the integral solution and considering the mentioned profile for velocity and temperature, we would have:

$$
\left\{\begin{array}{c}
U=\frac{g \beta \rho_{\omega} \Omega \partial^{3}}{12 \lambda v}\left[-\eta^{4}+3 \eta^{3}-3 \eta^{2}+\eta\right] \\
\theta=\left(T-T_{\infty}\right)=\frac{\rho_{\mathrm{W}} \Omega \partial}{2 \lambda}\left(-\eta_{\mathrm{T}}{ }^{4}+2 \eta_{\mathrm{T}}{ }^{3}-2 \eta_{\mathrm{T}}+1\right)
\end{array}\right.
$$

Where, $\eta=\mathrm{y} / \partial \leq 1$ and $\eta_{\mathrm{T}}={ }^{\mathrm{y}} / \partial_{\mathrm{T}} \leq 1$

The relation between thermal boundary layer thickness and hydrodynamic boundary layer thickness may be shown as follows:

$\partial_{\mathrm{T}(\mathrm{X}, \mathrm{T})=\Omega} \partial(\mathrm{X}, \mathrm{T})$

Putting equation 4 into the following integrals and solving these two integrals simultaneously,

$$
\begin{aligned}
& \frac{\partial}{\partial \mathrm{t}} \int_{0}^{\delta} \mathrm{Udy}+\frac{\partial}{\partial \mathrm{x}} \int_{0}^{\delta_{\mathrm{nf}}} \mathrm{U}^{2} \mathrm{dy}=\mathrm{g} \beta_{\mathrm{nf}} \int_{0}^{(\Omega \delta)_{\mathrm{nf}}}\left(\mathrm{T}-\mathrm{T}_{\infty}\right) \mathrm{dy}-\vartheta_{\mathrm{nf}}\left(\frac{\partial \mathrm{U}}{\partial \mathrm{y}}\right)_{\mathrm{y}=0}=0 \\
& \frac{\partial}{\partial \mathrm{t}} \int_{0}^{\Omega \delta} \theta \mathrm{dy}+\frac{\partial}{\partial \mathrm{x}} \int_{0}^{(\Delta \delta)_{\mathrm{nf}}}\left(\mathrm{T}-\mathrm{T}_{\infty}\right) \mathrm{Udy}=\frac{\vartheta_{\mathrm{nf}}}{\operatorname{Pr}_{\mathrm{nf}}}\left(\frac{\partial \mathrm{T}}{\partial \mathrm{y}}\right)_{\mathrm{y}}=0
\end{aligned}
$$

$\Omega$ may be obtained as equation 7 . (considering $\partial / \partial \mathrm{t}=0$ for steady-state conditions and $\ln \operatorname{Pr}=\mathrm{k}$ )

$$
\Omega=1.576 \times 10^{-4} \mathrm{~K}^{4}-4.227 \times 10^{-3} \mathrm{~K}^{3}+4.282 \times 10^{-2} \mathrm{~K}^{2}-0.1961 \mathrm{~K}+0
$$

According to what is observed, $\Omega$ is a function of $\operatorname{Pr}$ and $\operatorname{Pr}$ is as a function of nanofluid viscosity, so the amount of $\Omega$ is noticeably changed with Pr.

In this paper, different models of viscosity have been applied. Different parameters are effective on a nanofluid viscosity which from, the particles shape and the shear exerted onto fluid are of the most significance [17]. Regarding to the experimental and practical 
researches, investigators have found that viscosity is dependent on the method of preparation of nanoparticle as well [18]. Nanoparticles, because of very fine structure, make a stable and homogeneous state when solving in the base fluid. This, causes the nanofluids are considered similar to the base fluids as mono-phase. Since, temperature raising causes increase in the nanoparticles mean diameter [19], temperature is taken constant in this paper for precise solution of the integrals. The mean diameter of nanoparticles is assumed to be $32-50 \mathrm{~nm}$ and the calculations have been done for UHF and UWT boundary conditions. After solving the integrals, the parameters are substituted in $\mathrm{Nu}$ and the effects of $\Omega$ changes on $\mathrm{Nu}$ are investigated.

The Maxwell Wasp model is chosen for Nu calculations, which has agreement with the experimental results [20]. The average Nusselt number along the wall may be obtained by the following equation [21].

$$
\overline{\mathrm{Nu}_{\mathrm{nf}}}=\frac{\overline{\mathrm{h}_{\mathrm{nf}} \mathrm{L}}}{\mathrm{k}_{\mathrm{bf}}}
$$

Meanwhile, the average Nusselt numbers are different for UHF and UWT boundary conditions. For UWT boundary condition [21]:

$$
\overline{\mathrm{Nu}_{\mathrm{nf}}}=\frac{4 \sqrt{5}}{3 \Delta_{\mathrm{nf}}}\left[\frac{\beta_{\mathrm{r}} \mathrm{k}_{\mathrm{r}}^{4}}{378 v_{\mathrm{r}}^{2}\left(9 \Delta_{\mathrm{nf}}-5\right)} \mathrm{Gr}_{\mathrm{bf}}\right]^{\frac{1}{4}}
$$

Also, for UHF boundary condition [21]:

$$
\overline{\mathrm{Nu}_{\mathrm{nf}}^{*}}=\frac{6}{5}\left[\frac{2 \beta_{\mathrm{r}} \mathrm{k}_{\mathrm{r}}^{4}}{27 \nu_{\mathrm{r}}^{2}\left(9 \Delta_{\mathrm{nf}}-5\right) \Delta_{\mathrm{nf}}^{4}} \mathrm{Gr}_{\mathrm{bf}}^{*}\right]^{\frac{1}{5}}
$$

$\mathrm{Gr}_{\mathrm{bf}} *$ is the modified Grashof number [21]:

$$
\mathrm{Gr}_{\mathrm{bf}}^{*}=\frac{\mathrm{g} \beta \rho_{\mathrm{w}} \mathrm{L}^{4}}{\mathrm{~K}_{\mathrm{bf}} \vartheta_{\mathrm{bf}}{ }^{2}}
$$

The boundary-layer change rate is

$$
\mathrm{f}(\Delta)=\frac{9 \Delta_{\mathrm{bf}}^{5}-5 \Delta_{\mathrm{bf}}^{4}}{9 \Delta_{\mathrm{nf}}^{5}-5 \Delta_{\mathrm{nf}}^{4}}
$$

The $\varepsilon$ function (expressing the heat transfter performance) is [19]

$$
(\%)=100\left[\left(\frac{\beta_{\mathrm{r}} \mathrm{k}_{\mathrm{r}}^{4}}{v_{\mathrm{r}}^{2}} \mathrm{f}(\Delta)\right)^{\alpha}-1\right]
$$

$\alpha$ varies with different boundary conditions, $\alpha=1 / 5$ for UHF and $\alpha=1 / 4$ for UWT. Also, the $r$ index states the nanofluids/base fluids ratio.

The nanoparticles concentration is shown by subscript $f$ and we use the available relations for obtaining viscosity, constant temperature specific heat and $\beta$ :

$$
\begin{aligned}
& \rho_{\mathrm{nf}}=(1-\varphi) \rho_{\mathrm{nf}}+\varphi \rho_{\mathrm{p}} \\
& \left(\mathrm{C}_{\mathrm{p}}\right)_{\mathrm{nf}}=(1-\varphi)\left(\mathrm{C}_{\mathrm{p}}\right)_{\mathrm{bf}}+\varphi\left(\mathrm{C}_{\mathrm{p}}\right)_{\mathrm{p}} \\
& \left(\rho \beta_{\mathrm{nf}}\right)=(1-\varphi)(\rho \beta)_{\mathrm{bf}}+\varphi(\rho \beta)_{\mathrm{p}}
\end{aligned}
$$

For the calculation of nanofluid conductivity, the Wasp model has been used [20]: 


$$
\mathrm{K}_{\mathrm{r}}=\frac{\mathrm{K}_{\mathrm{p}}+2 \mathrm{~K}_{\mathrm{bf}}-2 \varphi\left(\mathrm{K}_{\mathrm{bf}}-\mathrm{K}_{\mathrm{P}}\right)}{\mathrm{K}_{\mathrm{p}}+2 \mathrm{~K}_{\mathrm{bf}}+\varphi\left(\mathrm{K}_{\mathrm{bf}}-\mathrm{K}_{\mathrm{p}}\right)}
$$

As stated, for investigation of viscosity effects, four viscosity models have been used. The first model which is introduced for nanofluids, is the Brinkman model [22]:

$$
\mu_{\mathrm{r}}=\frac{\mu_{\mathrm{nf}}}{\mu_{\mathrm{bf}}}=\frac{1}{(1-\varphi)^{\frac{5}{2}}}
$$

The second model is the model which was presented by Einstein`s [23]:

$$
\mu_{\mathrm{r}}=\frac{\mu_{\mathrm{nf}}}{\mu_{\mathrm{bf}}}=(1+2.5 \varphi) \text { for } \varphi<0.05
$$

The third model has been presented by considering the Brownian movement [24]:

$$
\mu_{\mathrm{r}}=\frac{\mu_{\mathrm{nf}}}{\mu_{\mathrm{bf}}}=1+2.5 \varphi+6.17 \varphi^{2}
$$

And the fourth model, which was presented by Pak and Cho, is as followings [25]:

$$
\mu_{\mathrm{r}}=\frac{\mu_{\mathrm{nf}}}{\mu_{\mathrm{bf}}}=1+3.911 \varphi+533.9 \varphi^{2}
$$

The calculations have been done for all of the mentioned viscosity models and for taking a better and more logical conclusion, temperature is taken around $22^{\circ} \mathrm{C}$, the nanoparticles mean diameter is considered as $32-50 \mathrm{~nm}$ and the maximum concentration is assumed to be $4 \%$. The results show the Nusselt changes with viscosity models, particles size, Grashof number for Ag for both UHF and UWT boundary conditions.

\section{RESULTS AND DISCUSSION}

Considering the assumptions mentioned in the previous part, the properties of Ag were obtained. According to different Gr numbers, volume fractions and viscosity models, the UHF and UWT Nusselt numbers were obtained (Tables 1-4).

Table 1: Average Nusselt Number nanofluids (Ag/Water) Model (I)

\begin{tabular}{|c|c|c|c|}
\hline $\mathrm{NU}_{\mathrm{UHF}}$ & & & \\
\hline $\mathrm{Gr}$ & $10^{3}$ & $10^{4}$ & $10^{5}$ \\
\hline$\Phi=1$ & 4.289 & 6.798 & 10.773 \\
\hline$\Phi=2$ & 4.409 & 6.987 & 11.074 \\
\hline$\Phi=3$ & 4.535 & 7.187 & 11.391 \\
\hline$\Phi=4$ & 4.661 & 7.387 & 11.585 \\
\hline $\mathrm{NU}_{\mathrm{UWT}}$ & & & \\
\hline$\Phi=1$ & 6.051 & 10.760 & 19.135 \\
\hline$\Phi=2$ & 6.276 & 11.1599 & 19.845 \\
\hline$\Phi=3$ & 6.494 & 11.548 & 20.536 \\
\hline$\Phi=4$ & 6.722 & 11.954 & 21.257 \\
\hline
\end{tabular}


Table 2: Average Nusselt Number nanofluids (Ag/Water) Model (II)

\begin{tabular}{|c|c|c|c|}
\hline $\mathrm{NU}_{\mathrm{UHF}}$ & & & \\
\hline $\mathrm{Gr}$ & $10^{3}$ & $10^{4}$ & $10^{5}$ \\
\hline$\Phi=1$ & 4.435 & 6.639 & 10.773 \\
\hline$\Phi=2$ & 4.409 & 6.996 & 11.074 \\
\hline$\Phi=3$ & 4.535 & 7.109 & 11.391 \\
\hline$\Phi=4$ & 4.661 & 7.387 & 11.585 \\
\hline $\mathrm{NU}_{\mathrm{UWT}}$ & & & \\
\hline$\Phi=1$ & 6.051 & 10.760 & 19.135 \\
\hline$\Phi=2$ & 6.276 & 11.599 & 19.845 \\
\hline$\Phi=3$ & 6.494 & 11.548 & 20.536 \\
\hline$\Phi=4$ & 6.722 & 11.954 & 21.257 \\
\hline
\end{tabular}

Table 3: Average Nusselt Number nanofluids (Ag/Water) Model (III)

\begin{tabular}{|c|c|c|c|}
\hline $\mathrm{NU}_{\text {UHF }}$ & & & \\
\hline $\mathrm{Gr}$ & $10^{3}$ & $10^{4}$ & $10^{5}$ \\
\hline$\Phi=1$ & 4.189 & 6.639 & 10.521 \\
\hline$\Phi=2$ & 4.412 & 6.992 & 11.082 \\
\hline$\Phi=3$ & 4.542 & 7.199 & 11.409 \\
\hline$\Phi=4$ & 4.673 & 7.406 & 11.738 \\
\hline $\mathrm{NU}_{\text {UWT }}$ & & & \\
\hline$\Phi=1$ & 5.948 & 10.577 & 18.8096 \\
\hline$\Phi=2$ & 6.316 & 11.231 & 19.972 \\
\hline$\Phi=3$ & 6.645 & 11.816 & 21.012 \\
\hline$\Phi=4$ & 6.7898 & 12.074 & 21.471 \\
\hline
\end{tabular}

Table 4: Average Nusselt Number nanofluids (Ag/Water) Model (IV)

\begin{tabular}{|c|c|c|c|}
\hline $\mathrm{NU}_{\text {UHF }}$ & & & \\
\hline $\mathrm{Gr}$ & $10^{3}$ & $10^{4}$ & $10^{5}$ \\
\hline$\Phi=1$ & 4.053 & 6.423 & 10.1798 \\
\hline$\Phi=2$ & 3.972 & 6.296 & 9.978 \\
\hline$\Phi=3$ & 3.922 & 6.216 & 9.852 \\
\hline$\Phi=4$ & 3.873 & 6.138 & 9728 \\
\hline $\mathrm{NU}_{\mathrm{UWT}}$ & & & \\
\hline$\Phi=1$ & 5.629 & 10.011 & 17.802 \\
\hline$\Phi=2$ & 5.450 & 9.692 & 17.235 \\
\hline$\Phi=3$ & 5.314 & 9.451 & 16.806 \\
\hline$\Phi=4$ & 5.184 & 9.129 & 16.393 \\
\hline
\end{tabular}


At $\mathrm{Gr}=10^{5}$ (as the highest Gr number), the graphs were depicted for Ag in both UHF and UWT for a better demonstration and observing the viscosity models behavior (Fig. 27).

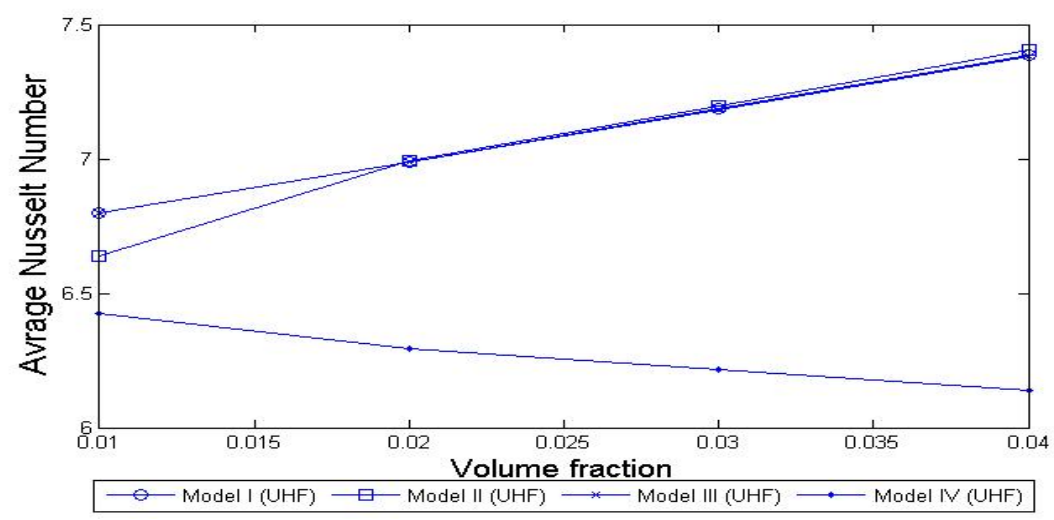

Fig. 2: Nusselt number versus volume fraction for different viscosity models at UHF (nanoparticle: $\mathrm{Ag} / \mathrm{Gr}=10^{3}$ )

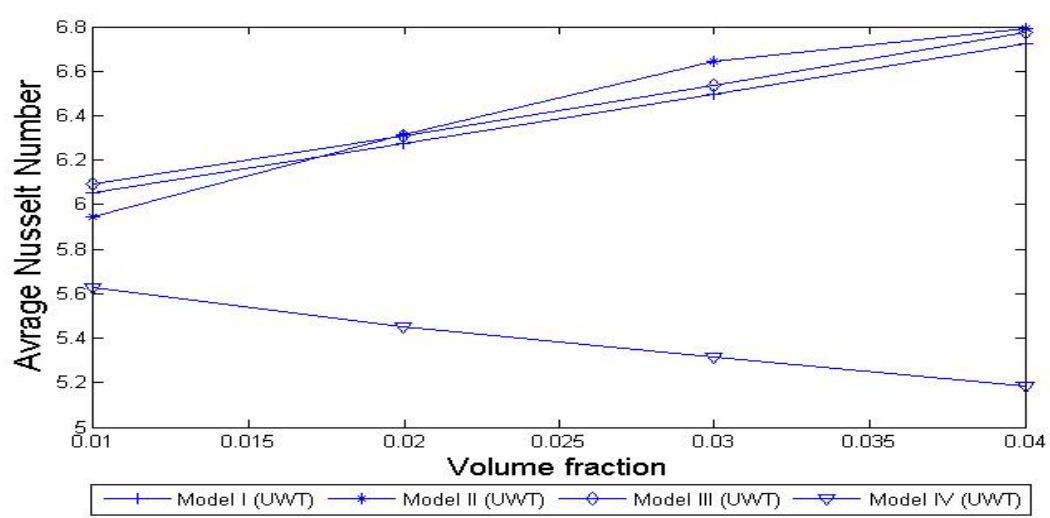

Fig. 3: Nusselt number versus volume fraction for different viscosity models at UWT (nanoparticle $\mathrm{Ag} / \mathrm{Gr}=10^{3}$ )

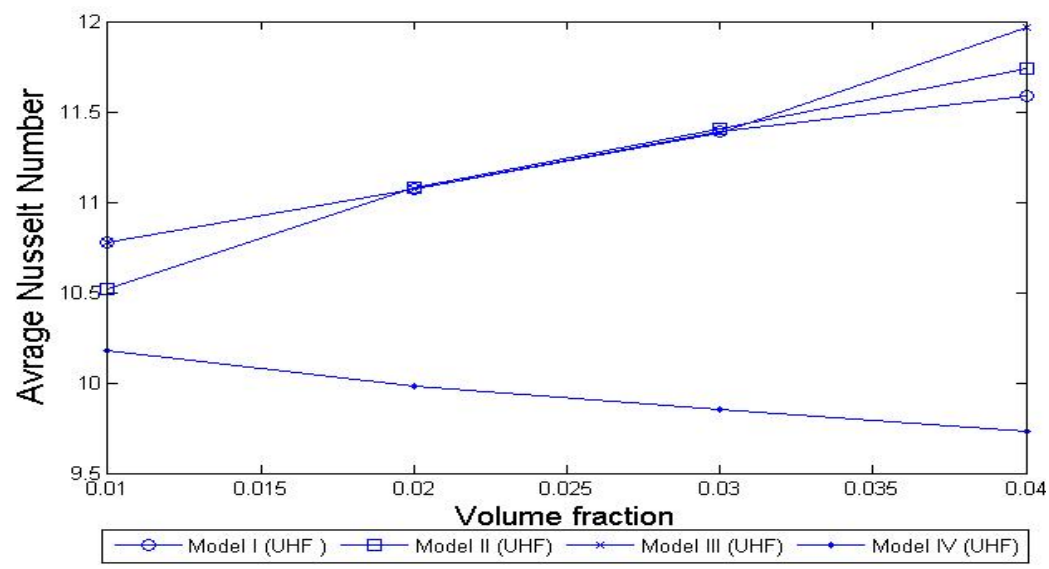

Fig. 4: Nusselt number versus volume fraction for different viscosity models at UHF (nanoparticle: $\mathrm{Ag} / \mathrm{Gr}=10^{4}$ ). 


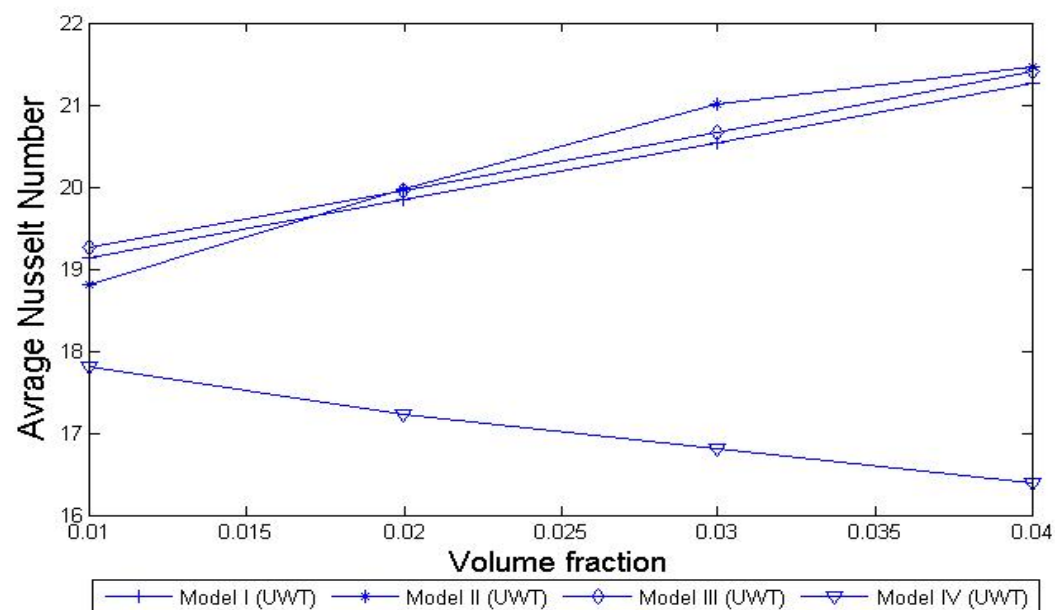

Fig. 5: Nusselt number versus volume fraction for different viscosity models at UWT (nanoparticle $\mathrm{Ag} / \mathrm{Gr}=10^{4}$ )

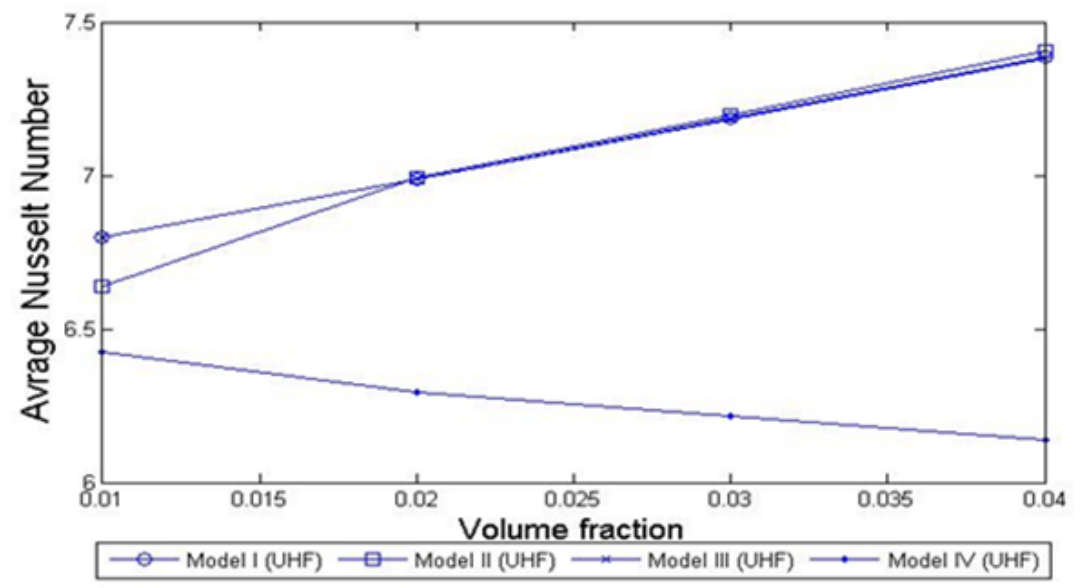

Fig. 6: Nusselt number versus volume fraction for different viscosity models at UHF (nanoparticle: $\mathrm{Ag} / \mathrm{Gr}=10^{5}$ )

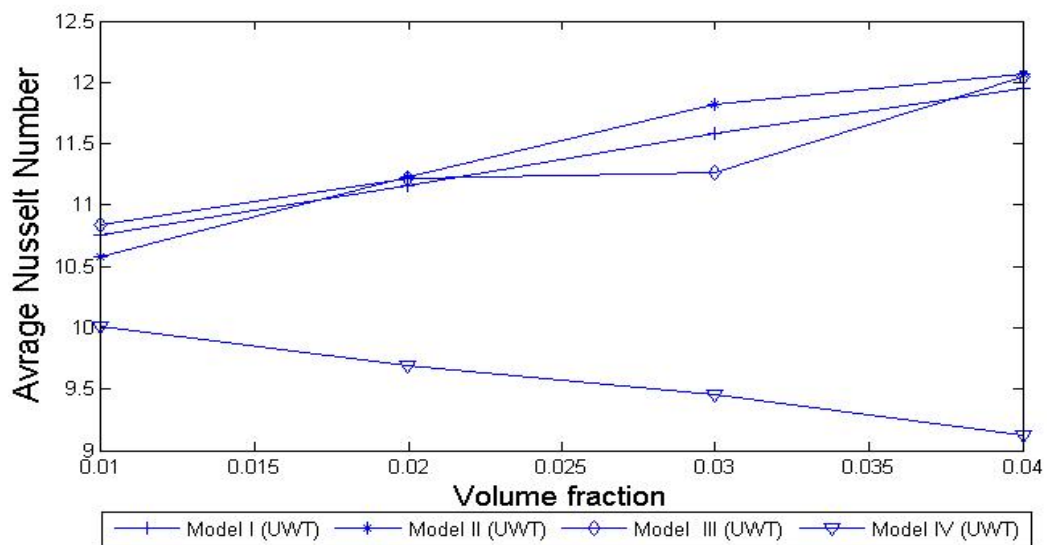

Fig. 7: Nusselt number versus volume fraction for different viscosity models at UWT (nanoparticle: $\mathrm{Ag} / \mathrm{Gr}=10^{5}$ ) 


\section{CONCLUSION}

The Pak and Cho viscosity model predicts a higher increase in viscosity when adding more nanoparticles and this behavior, causes nonconformity with the other models. For prediction of nanofluids (containing metal or metal oxide particles) free convection heat transfer, the Brinkman model, the Einstein model and the Brownian movement model are proposed to be applied for précise calculations. The free convection heat transfer coefficients of Ag nanofluid increase by increasing the nanoparticles volume fraction to $4 \%$. Thus for both the UWT and UHF surface thermal conditions, the examination of two viscosity models leads to constrasted conclusions. The use of the experimental correlation for the viscosity leads only to a weak enhancement (less than 1\%) with a trend to a deterioration phenomenon with increasing the particle concentration in the considered range.

\section{REFERENCES}

[1] Drexler, Erik . K., "Engines Of Creation”., London: Publisher Not Mention, 1990.

[2] Maxwell, Clerk. J., "Electricity And Magnetism". Oxford:Clarendon Press, 1873.

[3] Nada, Abu. E., Chamkha J. Ali.,, "Effect Of Nanofluid Variable Properties On Natural Convection In Enclosure", International Journal Of Thermal Sciences 49. 479-91 (2010).

[4] S.E.B. Maïga, S.J. Palm, C.T. Nguyen, G. Roy, N. Galanis, "Heat Transfer Enhancement By Using Nanofluids In Forced Convection Flows", International Journal Of Heat And Fluid Flow 26. 530 (2005).

[5] S.M. Foutukian, M. Esfahani, "Experimental Study Of Turbulent Convective Heat Transfer And Pressure Drop Of Dilute Cuo/Water Nanofluids Inside A Circular Tube", International Journal Of Heat And Mass Transfer 37. 214-19 (2010).

[6] Y. Xuan, Q. Li, "Investigation On Convective Heat Transfer And Flow Features Of Nanofliuds", Journal Of Heat Transfer 33. 151 (2005).

[7] D. Wen, Y. Ding, "Experimental Investigation Into Convective Heat Transfer Of Nanofluids At Entrance Region Under Laminar Flow Conditions", International Journal Of Heat Mass Transfer 47. 51812004.

[8] S.Kumar Et Al. "Analysis Of Flow And Thermal Field In Nanofluid Using A Single Phase Thermal Dispersion Model”. Applied Mathematical Modelling 34 573-92

[9] K.Khanafer, K.Vafai, Marilyn Lightstone, "Bouyancy-Driven Heat Transfer Enchancement In Two-Dimensional Enclosure Utilizing Nanofluids",International Journal Of Heat And Mass Transfer 46. 3693-53 (2003).

[10] E.Büyükögüt, "Natural Convection Of Water Based Nanofluids In Inclined Enclosure With Heat Source", International Journal Of Thermal Sciences 48. 2063-73 (2009).

[11] S.A Putnam, D.G. Cahill, P.V. B Braun, "Thermal Conductivity Of Nanoparticle Suspensions", Journal Of Applied Physics 995

[12] Y. Ding, H. Alias, D. Wen, R.A. Williams, "Heat Transfer Of Aqueous Suspensions Of Carbon Nanotubes, Int. J. Heat and Mass Transfer, Vol. 49 pp. 240-250, 2006

[13] H.E. Patel, S.K. Das, T. Sundararajan, A. S. Nair, B. George, T. Pradeep, "Thermal Conductivites Of Naked And Monolayer Protected Metal Nanoparticle Based Nanofluids. Manifestation Of Anomalous Enhancement And Chemical Effect", Applied Physics Letters 83 (14), 2931-2933

[14] H.Ahmari, S.Gh.Etemad, "Stability Of Nanofluids", Proceeding Of 1st Conference Of Nanotechnology In Environments 1, IUT974

[15] Y. Hang, H.S Park, J.K. Lee, W.H.Jung, "Thermal Conductivity Enhancement Of Nanofluids Current". Applied Physics, 61667

[16] J.Koo And C.Kleinstreuer, "A New Thermal Conductivity Model For Nanofluids”, Journal Of Nanoparticle Research 6577 (2004). 
[17] J. Buongiorno, L. W. Hu, S. Yip, "Nanofluid Coolants For Advanced Nuclear Power Plants", Nano Technology Workshop, MIT, (2005).

[18] D.P. Kulkarni, D.K. Das, R.S.Vajjha, "Application Of Nanofliuds In Heating Building And Reducing Pollution", International Journal Applied Energy 86 .2566-73 (2009).

[19] S.K. Das, N. Putra, P. Thiesen, W.Roetzel, " Temperature Dependence Of Thermal Conductivity Enhancement For Nanofluids", Journal Of Heat Transfer (ASME)125: 567 (2003).

[20] J.C. Maxwell, "A Treatise Of Electricity And Magnestism", Third Ed. Clarendon Oxford, P: 382, 1904.

[21] G. Polidori, S. Fohanno, C. T. Nguyen, “A Note On Heat Transfer Modeling Of Newtonian Nanofluids In Laminar Free Convection”, International Journal Of Thermal Science 46 739-44

[22] H. C. Brinkman, "The Viscosity Of Concentrated Suspension And Solutions",. Journal Chemistry Physics 20 571-81

[23] A. Einstein, "Investigation On The Theory Of Brownian Motion", Dover, New York, 1956.

[24] D.Orozeco, "Hydrodynamic Behavior Of Polar Particle",. 42375-396

[25] B.C. Pak, Y. Cho, "Hydrodynamic And Heat Transfer Study Of Dispersed Fluids With Submission Metallic Oxide Particle", Experiments Heat Transfer 11 151-70 


\section{NOMENCLATURE}

$\begin{array}{ll}\operatorname{Pr} & \text { Prandtl number } \\ C p\left[\mathrm{~kg}^{-1} \mathrm{~K}^{-1}\right] & \text { heat capacity } \\ k\left[W \mathrm{~m}^{-1} \mathrm{~K}^{-1}\right] & \text { thermal conductivity } \\ \mu & \text { viscosity } \\ U H F & \text { uniform heat flux } \\ U W T & \text { uniform wall temperature } \\ v\left[\mathrm{~m}^{2} \mathrm{~s}^{-1}\right] & \text { kinematic viscosity } \\ \mathrm{Gr} & \text { Grashof Number } \\ \mathrm{Gr}{ }^{*}{ }_{b f} & \text { modified Grashof number } \\ \mathrm{Nu} & \text { Nusselt number }\end{array}$

\section{Greek symbols}

$\delta_{\mathrm{t}}$

$\Delta$

$\varphi$

$\beta$

$\epsilon$

$\mathrm{A}$

$\Omega$

\section{Subscripts}

$p$

$b f$

$r$

\section{$p$}

thermal boundary layer thicknesses

dynamical boundary layer thicknesses

volume fraction

volumetric expansion coefficient

heat transfer performance

constant

ratio of thermal boundary layer thickness $\left(\delta_{T}\right)$ to that of the dynamical $(\delta)$

nanoparticle

base fluid

nanofluid / base fluid rate 